\title{
DEFINING COMMUNITY BASED GOVERNANCE FOR INFORMAL HOUSING \& SETTLEMENTS WITHIN TRINIDAD AND TOBAGO
}

\author{
Wayne Chaman Huggins \\ Faculty of Engineering, The University of the West Indies, Trinidad \\ Email: wchuggins@yahoo.com
}

\begin{abstract}
Encouraging and supporting Community Based Governance for Informal Housing and Settlements to achieve a sustainable built environment is essential. However, this will be the greatest challenge facing countries as they become more urbanized. Governance has become difficult to define and measure, much less described as a theory that can be modelled and applied to policy and in making decisions. The difficulty in definition was traced both to the evolving roles of the planner; and ontological and epistemological paradigms that have shaped research.

This research defined Community Based Governance as a theory. This was explored using a Grounded Mixed Methods to integrate quantitative and qualitative data. Using intersectionality and structuration, the outcomes were examined.

Initial results from Trinidad suggest that the reformulated theory of Community Based Governance has demonstrated failures and unsustainability of the public sector's squatter regularisation programme where Community Based Governance though essential, is undermined. However, this contradicts the success that the programme claims.
\end{abstract}

Keywords: Community Based Governance, Grounded Mixed-Methods. Housing and Settlements, Intersectionality, Structuration.

https://doi.org/10.47412/XLDF7466

\section{Introduction}

The United Nations has predicted that by 2050, most of the world's population will be residing in cities [1]. Cities now offer higher expectation for a better quality of life. It is often the only area where rural communities can relocate when there are total crop failures and other catastrophes from adverse and changing weather and climate [2]. The growth in urbanization has occurred through Community Based Organisations. Families who have benefited with the opportunity to improve their lives, include: new rural migrants; urban low income and working poor families; homeless and roofless families; and asylum seekers and refugees from other countries. 
Unfortunately, there is a dark side to urbanization. Many families have faced exclusion or are denied housing because of their political, ethnic and religious attributes [3].

This research is part of on-going research towards defining a model for Community Based Governance in informal housing and settlements in Latin America and the Caribbean. This first paper explores some definitional issues, modelling and an application to the squatter regularisation programme in Trinidad. Subsequent papers will explore methodological issues in applying this model to other countries, and analysis using mixed methods research.

\section{Governance}

Governance is not a Western idea as often promulgated in the literature. The concept of Governance goes to over 500 BC to Confucius in China [4]. The World Bank in 1991 defined Governance as a neutral concept meaning the "exercise of authority; control” [4]. As a synonym for Government, governance was further defined as "the political direction and control exercised over the actions of the members, citizens, or inhabitants of communities, societies, and states" [4]. The Bank later defined Governance as the manner in which power is exercised in the management of a country's economic and social resources for development [5, 6]. Government and Governance were once synonyms. Governments and Governance mean different things to different people. In separating Government from the National State, one can use Governance theory to examine how well or bad a government is being administered [7].

The State is the mechanism and context in what values- goods, services, and opportunities are created and distributed among people. The state is established and is a stable situation. Over time, the institutions and political power all constitute the idea of the nation state [7]. In this regard, the idea of the State is bigger and more relevant that Government. It's the State's reach that is what is important.

The World Bank and other institutions have focused on the normative idea of Good Governance where the dimensions of social issues such as politics and legitimacy were deliberately ignored or taken as a given $[4,6]$. However, these same institutions have declared that socio-political issues were identified as impediments to reform to Good Governance [4, 5, 8].

Governance has at least eight (8) dimensions as cited by [7], from the United Nations Economic and Social Commission for Asia and the Pacific UNESCAP.

These Eight (8) dimensions of Governance in the normative sense, are as follows:

(1) Participation;

(2) Rule of Law;

(3) Transparency;

(4) Responsiveness;

(5) Consensus Oriented;

(6) Equity and Inclusiveness; 
(7) Effectiveness and Efficiency; and

(8) Accountability.

Another dimension, "Legitimacy" is not included, though defined in the notion of a social contract between the rulers and the ruled is one with a bargain with mutual responsibility. Failure of this social contract can lead to loss of legitimacy [4]. Legitimacy has also been defined in terms of level of democracy [6]. Government as a formal institution refers to the monopoly of legitimate coercive power [9]. Legitimacy occurs when a social contract is fulfilled as well as a right enshrined in democracy.

These dimensions of Governance as listed (except Legitimacy) have been supported by the World Bank as it relates to supporting the institutions with the State or the Government Sector. There was no support for informal and Community Based or Non-Governmental Organisations [5].

Citizens respect the procedures and institutions of legitimate government even if they do not respect particular actors [4]. This suggests that only genuine participation in the political process can provide a government with unshakeable and permanent legitimacy. Participation can link citizens with decision making. Plurality of institutions outside of Government offers opportunity for informal representation enabling people to reach up to governments [4].

However, research done by the World Bank further indicated that there is no link between the mechanism of formal representation and the effectiveness of government [4]. There is also the notion that community- based governance within popular organisations reinforce accountability by constraining government agency abuses [4]. This happens when authoritarian member in controlling local organisations were effective in channeling concerns to the state [4]. However, this depended on the structure of the power relations held by the common groups [4].

The World Bank also identified Three (3) aspects of governance: (a) the form of political regime; (b) the process by which authority is exercised in the management of a country's economic and social resources for development; and (c) the capacity of governments to design, formulate, and implement policies and discharge functions [6]. Governments also have different levels of Government: Macro, Meso, and Micro [8].

The normative view explicitly ignores the socio-political dimensions and by extension, the true nature of Governance as the manner in which power is utilised. This omission is acknowledged by the World Bank [5]. In addition, supporting the existing Government institutions carried big risks. Many of the Governments in Latin American and the Caribbean have had Colonial historical and cultural contexts that vary widely leading to different outcomes, [4]. For example, during Colonial periods, the colonial civil service was never accountable to those who were ruled. In the postcolonial period, this has not changed [4]. The legacy lives on in the institutions where accountability was centric, and in the post-colonial period, responding to clan and political pressure from the clans and political entities that now controlled government [4].

The literature also suggests that the multilateral lending agencies such as the World Bank and the Inter-American Development Bank have supported research and development programmes aimed at understanding Governance for specific situations such as Land. However, these are noticeably quantitative constructs. There is need for more work as it relates land to informal housing and settlements in urbanization. In the late 1990s, there were concerns raised that there were 
unresolved issues of land that are not easily addressed by urbanisation [10]. It is likely that with the trend for an increasingly urbanized world that these issues will become more critical.

With the changing notion of Governance is the parallel trajectory of the evolution of the role of the planner. The Master Planning process is now under question and a relic of the past. This was reflected in the 1960s where citizens were agitating for greater involvement in the planning process. However, the outcomes were described from varying degrees of power held by the citizens as a ladder with eight rungs from non-participation, to tokenism and participation, [11].

Parallel with the evolution of the profession has been the evolution of research methodologies. No longer is Positivism at center stage. Over the last 20 years, World Wide, there has been a growing need to reconsider qualitative aspects particularly in the field of nursing, medicine and sociology. Mixed Methods approaches are now becoming more acceptable in research thus offering for the first time an opportunity to revisit earlier ideas that dismissed qualitative data as unscientific and the notion of social science as a paradox.

A watershed moment is at hand where important and often rejected or unaccepted interpretivist concepts such as Intersectionality [12] and Structuration [13] and [14]. Recent research work has shown the contribution of Mix Methods Research to a greater understanding of behavioral phenomena using qualitative techniques and now provide the opportunity for advancing these methodologies based on grounded, mixed methods approaches that lead to greater integration of qualitative and quantitative information [15].

Intersectionality can be used as a framework for analysing some of these urban issues. The notion of Intersectionality provides us with a lens for understanding how people are often disadvantaged by interlocking power systems that compound various characteristic visible identifiable traits such as ethnicity, gender, nationality, religion etc. [12]. The Intersectionality framework has been applied in examining outcomes in respect of asylum seekers, refugees and the homeless among others and the new urban issues that these migrants face during the journey and process of urbanization [14]. These issues are not mirrored in the discourse of governance of urbanisation as issues needing attention, rather than an ethnographic journey that is experienced. This suggest that these issues are ignored or made worse during urbanization and must therefore be a key component to address in governance of the urbanization process.

Another important framework for analysis is Structuration [13]. The theory of structuration as distinct from Structurism focuses on the reproduction of social systems where both the structure and the agency (human agency) are seen as a duality, not as a mechanical process but as a doing process. The focus is on human doings in their environment shaping the social environment [14].

If we acknowledge some basic insights about urbanisation as the result of a process of Governance, where not only individuals, but whole families and villages are on the move to better themselves; then valuable insights would be gleamed to advance the concept of community based governance and sustainable urbanisation. This renewed focus must necessarily treat with for example, the long standing issues of the Myth of the Megacity Solution [10]. It translates to a governance issue.

There is also growing interest to enhance public involvement in Governance to secure quality and legitimacy in the democratic decision-making process [16]. With this interest and growing demand is the widening of political space. In this context, there is recognition that one can use these spaces 
to view participation to explore issues of power and the differences in the making and shaping of spaces for participation in development [16]. By integrating the notion of power into a concept of Governance, the literature suggests that Governance can be examined in the context of Governance spaces. Where it is the interaction of these spaces with power differences can add richly to understanding Governance.

Using space characterization, the sovereign state can be considered to have "sovereign space" this space is managed by Governments. Government, whose members are from political parties then have control of Government Governance space. Government exercises control of the sovereign space through the government institutions. This is how Government power is replicated in these spaces created and can be explained by Governmentality Theory [17]. The areas not adequately governed or outside of the Government Governance space are still within the sovereign space.

With the entire sovereign space, including the government governance space, exists spaces that are created, reshaped, invited (by government), or allocated by government. Some are even captured or coerced [17].

But spaces on their own are meaningless if there is little understanding of how these are managed. Institutions, entities and groups of one of two people can be considered organisations. Each with its own sets of objectives and behaviors and in particular survival objectives [18].

An organization can be deconstructed into its basic elements to observe the structural and behavioral processes and how these come together to give the organization its life [18]. This deconstruction forces us to look at individuals and groups of people as they interact, to be viewed as an organization [18]. Thus political parties, NGOs, governments, are seen as organisations. These organisations have structures simply because they act as ordered instruments to achieving some stated or unstated goals. As a matter of recourse, the organization replicates itself through the delegation of power. This is what gives consistency of action. It can also explain the concept of Structuration.

However, the structure can belie the true nature of the organization [18]. The organization can be viewed as embedded in an institutional matrix [18]. This matrix comprises an Actions System that is comprised of the hierarchy of people, power structure of who is in charge, roles they perform and functions [18]. Beneath this is the Formal structure that speaks to processes [18]. However, this Formal structure, it is not really a Formal structure as it has a duality with an informal social structure that is adaptable. It's the interaction of the Formal structure and the informal adaptive social structure that gives the organization existence [18] (sounds like an element of structuration theory here). However, it is this said interaction that is the source of conflicts within the organization [18].

Many times when an organization is evaluated, we tend to look at the Actions system and the Formal system, while completely ignoring the informal adaptive social structures that exists. The Formal System operates in an environment of a paradox [18].

The divergence that one sees in operation is explained by the informal social structures. Taken as a whole, the entire organization can be seen as a Cooperative System, where in larger organisations, different cultures within the organization may emerge that rewrite rules and regulations and conduct into unwritten laws [18]. 
Reaffirming that Governments have a political dimension must mean that objectives of government may not equate that with the sovereign state. If one considers that the sovereign state and its space is embedded in a socio/political matrix, then both political power (political capital) and community spirit (social capital) can be derived. There can be conflicts within Government, and amongst Government, the Sovereign State and the Community Based Organisations, especially where their parochial interests that drive the survival of the Government (political and class interests) interact or collide with the Community Based Organisations (community and alternative political and class interests). The dynamics of this changes even further when Governments change and the balance of power behind governance changes.

\section{Community Based Governance}

Community Governance has been defined as the set of small group social interactions, that, with market and the state, determine economic outcomes [19]. Growth in Social Capital in a Community was the basis for Community spirit and Community Governance [19].

The forgoing have been assimilated and is conceptually modelled below in Fig. 1 to show the context of Community Based Governance within Governance spaces. This model shows the location of the Eight (8) plus (+) One (1) dimensions for Governance within the Sovereign and Government Space. Shown in this way, we can see that the Sovereign State is the rightful domain for the space of the Eight (8) dimensions of Good Governance and that these need to be insulated from Government's parochial interests, and the statutory duty of the Land Settlement Agency (LSA). In Trinidad and Tobago, this separation already exists for one aspect of the rule of law: between the Executive (Government) and the Judiciary, and between the Executive and the President as Head of State to preserve their respective independence. 


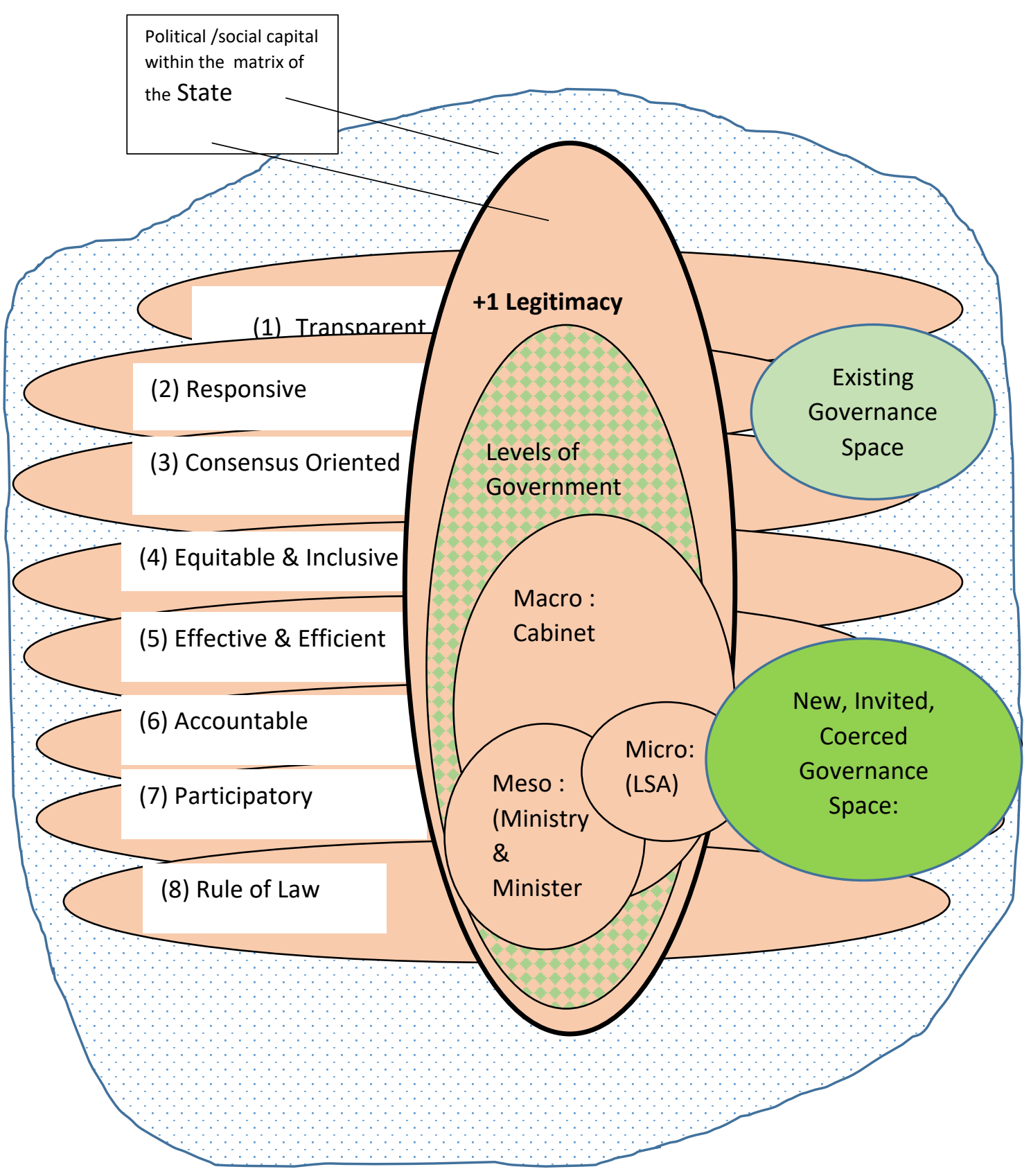

Figure 1: Initial Framework for Examining Governance

In defining a perspective of the Community Based Governance within a Community Governance Space, the following assumptions are proposed:

- The sovereign state is embedded in a socio / political, institutional matrix; has longevity and stable.

- Community based spaces and Governance (Community based Governance) is based on common aspirations of the community. 
- Governments have a political dimension and will support strategies that ensures political survival.

A definition for Community Based Governance can therefore be ascribed as the manner in which the power of the community, as defined by the Community Space where it has jurisdiction, is utilised in managing and controlling the social and economic resources at the community's disposal or use, for the community's development in accordance with the social contract, goals, aspirations and objectives of the community with that of the Community Based Organisation in that Community Space.

\section{Assessing Governance in Informal Housing and Settlements}

The Land Settlement Agency was established as body corporate under the State Land (Regularisation of Tenure) Act Number 25 of 1998, to administer the provisions of this law in Trinidad. The LSA is directed by the Minister and its board is selected by the Minister. Accountability in the general sense of measuring governance is through the Minister.

Two (2) of the key outputs of the LSA were the processing of Certificates of Comfort; and the Upgrade of Infrastructure on sites. The Certificate of Comfort is a temporary occupation license to protect those who applied for such protection from ejectment on State lands.

The upgrade of infrastructure is facilitated by the LSA. The LSA is tasked with upgrading 251 designated areas or squatter sites in Trinidad. In this paper, we will focus on just these two (2) outputs: Processing and grant of Certificates of Comfort; and Upgrade of Infrastructure.

It is proposed, that a preliminary Governance Framework would be applied to assess Governance using the eight (8) dimensions, as a matrix. The analysis will be from the perspective of the Minister who is responsible for the LSA, and also by the clients, the squatters, tenants and persons according to the law. This will provide a basis for improving the assessment model that is proposed. 


\section{Results}

\subsection{Certificate of Comfort Processing}

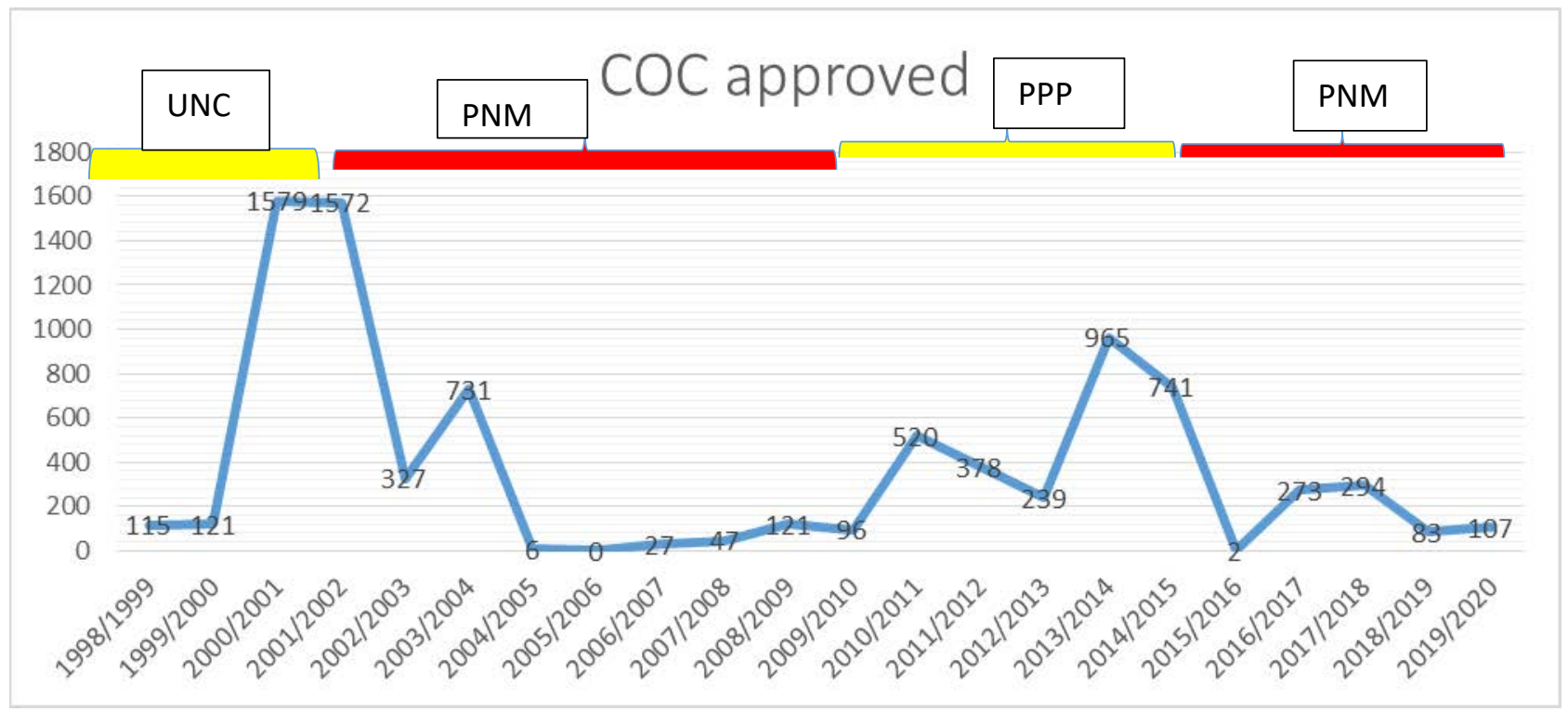

Figure 2: Certificates of Comfort approved from the financial years 1999 to 2020

The LSA received just over 22,000 applications for Certificates of Comfort by the end of year 2000.The LSA has issued approximately 8,000 certificates of comfort over the last 20 years.

\subsection{Infrastructure Upgrade}

The LSA over the period 1999 to 2019 developed approximately 20 sites out of 251 sites to the point that these can be transferred to the Municipal Corporation for maintenance and for the issuance of Statutory Leases and Deeds of Lease. This will take over 200 years to complete.

The outcomes in Table 1 and Table 2, are conceptual and indicate whether there is any accountability with an entity or stakeholder, in the general sense: yes or no, for each dimension. Further research through detailed studies will reveal the extent using for example, a Likert scale.

Table 1: COC Governance Matrix

\begin{tabular}{|l|l|l|l|l|l|}
\hline $\begin{array}{l}\text { Government Governance } \\
\text { (LSA) }\end{array}$ & \multicolumn{5}{l|}{ Stakeholders in COC outcomes } \\
\hline & Dimension & $\begin{array}{l}\text { Minister, other } \\
\text { Ministers \& } \\
\text { Cabinet }\end{array}$ & $\begin{array}{l}\text { Ministry of } \\
\text { Housing and } \\
\text { Urban } \\
\text { Development }\end{array}$ & $\begin{array}{l}\text { Squatter } \\
\text { Community }\end{array}$ & $\begin{array}{l}\text { All Squatter } \\
\text { Communities }\end{array}$ \\
\hline 1 & Transparency & Yes & no & no & no \\
\hline
\end{tabular}




\begin{tabular}{|l|l|l|l|l|l|}
\hline 2 & Accountability & Yes (political) & no & no & no \\
\hline 3 & $\begin{array}{l}\text { Effectiveness and } \\
\text { Efficiency }\end{array}$ & Yes & no & no & no \\
\hline 4 & Rule of Law & Yes & no & no & no \\
\hline 5 & Responsive & Yes & no & no & no \\
\hline 6 & Consensus Oriented & Yes & no & no & no \\
\hline 7 & Equitable and Inclusive & Yes & no & no & no \\
\hline 8 & Participatory & Yes & no & no & no \\
\hline+1 & Legitimacy & Yes & no & no & no \\
\hline
\end{tabular}

Table 2: Infrastructure Upgrade Governance Matrix

\begin{tabular}{|c|c|c|c|c|c|}
\hline \multicolumn{2}{|c|}{$\begin{array}{l}\text { Government } \quad \text { Governance } \\
\text { (LSA) }\end{array}$} & \multicolumn{4}{|c|}{ Stakeholders in Upgrade of Infrastructure outcomes } \\
\hline & Dimension & $\begin{array}{l}\text { Minister, other } \\
\text { Ministers \& } \\
\text { Cabinet }\end{array}$ & $\begin{array}{l}\text { Ministry of } \\
\text { Housing and } \\
\text { Urban } \\
\text { Development }\end{array}$ & $\begin{array}{l}\text { Squatter } \\
\text { Community }\end{array}$ & $\begin{array}{l}\text { All Squatter } \\
\text { Communities }\end{array}$ \\
\hline 1 & Transparency & yes & no & no & no \\
\hline 2 & Accountability & yes & $\begin{array}{l}\text { Yes } \\
\text { (financial } \\
\text { expenditure) }\end{array}$ & no & no \\
\hline 3 & $\begin{array}{ll}\text { Effectiveness and } \\
\text { Efficiency }\end{array}$ & yes & no & no & no \\
\hline 4 & Rule of Law & yes & no & no & no \\
\hline 5 & Responsive & yes & no & no & no \\
\hline 6 & Consensus Oriented & yes & no & no & no \\
\hline 7 & Equitable and Inclusive & yes & no & no & no \\
\hline 8 & Participatory & yes & no & $\begin{array}{l}\text { Tokenism \& } \\
\text { Therapy }\end{array}$ & no \\
\hline+1 & Legitimacy & yes & no & no & no \\
\hline
\end{tabular}

\section{Conclusion}

The major conclusion of this paper is the proposed definition for Community Based Governance grounded in a non-normative definition. From this definition, a new model of Governance is proposed. This has been used to explore a proposed framework for assessing Governance.

Preliminary analysis reveals that from the perspective of the LSA and the Government(s), the LSA was successful in the processing of the Certificates of Comfort and in the infrastructure upgrade. This is well documented in annual and achievement reports of the LSA that focuses on allocation and expenditure, rather than outcomes and outputs. However, this would be contrasted with the 
communities as failures in terms of all of the dimensions. For the clients, there would be loss in legitimacy from the failure to provide outcomes of security from ejectment and upgraded infrastructure (the social contract, expectations). Clients expected COC within a short period of time, and the slow pace of upgrade of infrastructure is leaving poor families trapped in poverty for at least 200 years to come.

Based on the foregoing model, there would be immediate concerns of Governance of the LSA that the framers of the legislation failed to address. In particular, accountability in the general sense to its clients, those who are landless and squatters. The LSA is only fully accountable to the Minister and Cabinet.

It raises an important issue in the overall governance whether the lack of reform of the LSA and lack of empowerment of the communities served the parochial interest of all Governments, and in whose interest it served, to allow this circumstance to exist and be maintained across several governments and political parties, for 20 years. This has to be explored not in the context of a normative Governance model, but based on the objectives of Government in Governing which includes the socio-political issues as proposed.

Further detailed analysis is required to developing this framework for assessing the Eight (8) plus One (1) dimensions of Governance. Such a framework could revolutionalise the way we prepare project/ progamme/ policies and project/progamme and policy management and review for sustainable development.

\section{References}

[1] UN Department of Economic and Social Affairs (UNDESA), The United Nations, New York: UN. Accessed February Thursday, 2019. https://www.un.org/development/desa/en/news/population/2018-revision-of-world-urbanizationprospects.html.

[2] W.C. Huggins. 2011. "Is Rapid Urbanisation in the Developing World a Natural Adaptation to Climate Change? Revisiting the Over-Urbanisation Debate." International Conference on Climate Change and Social Issues. Colombo: Institute of Human Development and Training (Sri Lanka) \& Toulouse Business School (France).

[3] J.W. Paller. 2015. "Informal Networks and Access to Power to Obtain Housing in Urban Slums in Ghana." Africa Today (Indiana University Press) Vol. 62. No.1 (Special Issue: The Politics of the Nonstate Provision of Public Goods in Africa): pp.31-55. Accessed February 22, 2019. https://www.jstor.org/stable/10.2979/africatoday.62.1.31.

[4] D. Brautigam. 1991. Governance and Economy, A Review. Policy Research, World Bank, Washington, DC: World Bank, 54.

[5] S. Lateef, C. Bryant, R. Harris, P. Isenman, G. Lamb, A. Rigo, and M. Shirley. 1992. Governance and Development. Study, Washington, DC: The World Bank. Accessed February 19, 2019. http://documents.worldbank.org/curated/en/604951468739447676/pdf/multi-page.pdf. 
[6] M. Stevens, R. Gonzales Cofino, E. Betancourt, and S. Gnanaselvam. 1994. Governance: The World Bank's Experience. Study, Washington, DC: The World Bank. Accessed February Tuesday, 2019. http://documents.worldbank.org/curated/en/711471468765285964/pdf/multi0page.pdf.

[7] E. Golshan. 2006. "Sovereignty, Governance and Government Performance." EROPA.

[8] J. Spanhove and K. Verhoest. 2007. Analyzing Government Governance at different. Paper for the EGPA SEMINAR FOR DOCTORAL STUDENTS AND JUNIOR RESEARCHERS, Institutuut Yoor de Overheid, KATHOLIEKE UNIVERSITEIT LEUVEN, Madrid: KATHOLIEKE UNIVERSITEIT LEUVEN. Accessed February Thursday, 2019. https://soc.kuleuven.be/io/pubpdf/IO0006005_egpa_spanhove.pdf.

[9] G. Stoker. 1998. "Governance as theory: five propositions." International Social Science Journal 50: 17-28.

[10] A. Mohammed. 1997. "The Myth of the Megacity Solution." Habitat Debate Vol. 3 (No.2): 26-27.

[11] S.R. Arnstein. 1969. "A ladder of citizen participation." Journal of the American Institute of Planners 35 (4): 216-224. doi:10.1080/01944366908977225.

[12] K. Crenshaw. 1989. "Demarginalizing the Intersection of Race and Sex:A Black Feminist Critique of Antidiscrimination Doctrine, Feminist Theory and Antiracist Politics." University of Chicago Legal Forum 1989 (1 Article 8). Accessed April 21, 2019. https://chicagounbound.uchicago.edu/cgi/viewcontent.cgi?article=1052\&context=uclf.

[13] R. Whittington 2015. "Giddens, Structuration Theory and Strategy as practice." In Cambridge Handbook of Strategy as Practice, 109-126. Accessed April 21, 2019. doi:10.10.1017/CC097811396811032.009.

[14] P. Kissoon 2015. Intersections of Displacement: Refugees' Experience of Home and Homelessness. Newcastle upon Tyne, UK: Cambridge Scholars Publishing.

[15] J. Greswell, C. Poth, and A. Onwuegbuzie. 2019. "Key Note Speakers." Third Regional Mixed Methods Research Conference: Integrating Qualitative and Quantitative Approaches: Tensions, Challenges and Possibilities. Port of Spain, March 26-28.

[16] A. Cornwall. 2002. "Making spaces, changing places: situation participation in development." Institute of Development Studies (170): 43.

[17] M. Taylor. 2007. "Community Participation in the Real World: Opportunities and Pitfalls in New Governance Space." Urban Studies (Routledge, Taylor \& Francis) 44 (2): 297-317.

United Nations. 2018. 2018 Revision of World Urbanization Prospects, Population Division.

[18] P. Selznick. 1948. "Foundations of the Theory of Organization." American Sociological Review 13 (1): 25-35. Accessed November Wednesday 6th, 2019. doi:10.2307/2086752.

[19] S. Bowles and G. Herbert. 2002. "Social Capital and Community Governance." The Economic Journal (Blackwell Publishers) 112 (November): F419-F436. 